\title{
The Null Effect of UVC Ceiling Light Exposure on SARS-CoV2
}

\author{
Waheeb E. Alnaser ${ }^{*}$ (1) , Amjad Z. Ghanem², Naser W. Alnaser ${ }^{3}$, Qasim Alaraibi ${ }^{2}$, \\ Fatima Alshaikh ${ }^{2}$ \\ ${ }^{1}$ Department of Physics, College of Science, University of Bahrain, Sakhir, Kingdom of Bahrain \\ ${ }^{2}$ Public Health Laboratory, Ministry of Health, Mananama, Kingdom of Bahrain \\ ${ }^{3}$ Department of Architecture and Interior Design, College of Engineering, University of Bahrain, Kingdom of Bahrain \\ Email: *walnaser@uob.edu.bh
}

How to cite this paper: Alnaser, W.E. Ghanem, A.Z., Alnaser, N.W., Alaraibi, Q. and Alshaikh, F. (2020) The Null Effect of UVC Ceiling Light Exposure on SARS-CoV2. Health, 12, 1481-1495. https://doi.org/10.4236/health.2020.1211108

Received: October 27, 2020

Accepted: November 24, 2020

Published: November 27, 2020

Copyright $\odot 2020$ by author(s) and Scientific Research Publishing Inc. This work is licensed under the Creative Commons Attribution International License (CC BY 4.0).

http://creativecommons.org/licenses/by/4.0/

\begin{abstract}
There has been some extensive research investigating the effect of Far Ultraviolet Radiation (UVC) on SARS and MARS. However, to the best of our knowledge, there have not been any detailed experiments looking at the effect of UVC on COVID-19 (now is called SARS-CoV2). Many researchers in this field believe that UVC destroys SARS-CoV2 because it warps the genetic material of the virus hurdling the viral particles from reproduction. In this paper, we report the result of our novel experiments on the effect of UVC on SARS-CoV2 using a commercially available UVC source, i.e. Krypton Disinfection lighting CM15W12V Series (wavelength of $222 \mathrm{~nm}$ ), which is sold and marketed for the disinfection of pathogens. The experiments were extended to study the effect of UVC exposure to Bacteria and Fungus. Our experiments show that UVC has no effects on SARS-CoV2 when it is close to the SARS-CoV2 culture plate $(4-5 \mathrm{~cm})$ or at a distance $(2.0$ to $2.9 \mathrm{~m})$, i.e. when fixed at the ceiling. This observation is important as the public seems to have the impression that commercial UVC ceiling light can kill SARS-CoV2 while this study has proven the opposite. Moreover, it shows no effect even when the UVC ceiling light is radiating on SARS-CoV2 for overnight. This proves that the intensity of the UVC from these devices is relatively low. However, the UVC light is found to be effective in destroying Bacteria and Fungus (part of pathogens), substantially, in $30 \mathrm{sec}$, and completely kills them when it's at $2.9 \mathrm{~m}$ (or less) away from them and exposure for one day. This indicates that the UVC light is effective for bacteria disinfection.
\end{abstract}

\section{Keywords}

COVID-19, SARS-CoV2, UVC, Pathogens, UVC Exposure 


\section{Introduction}

Some hospitals, as early as 80 years ago, had already equipped patients' rooms with an Ultraviolet light, to warp and zap pathogens, i.e. the so-called upper-room UV germicidal irradiation [1]. Nowadays, societies encourage this practice to rebound from the SARS-CoV2 pandemic and hope to immolate pathogens out of the air in social gathering places, in order to prevent/reduce the spread of virus. The Ultraviolet light (UVC) destroys the genetic material in pathogens, DNA in bacteria and fungi, RNA in viruses, hurdling them from reproducing.

Figure 1 demonstrates how can UVC lights kill pathogens and stop their reproduction by fixing them in each corner of a room. The use of a ceiling fan is also important to draw polluted air upward so that all floating bacteria, viruses and fungi are zapped more quickly and all surfaces in the room are disinfected.

The reason why the germicidal fixtures employ UVC is due to its short wavelength and energy when compared to UVA and UVB. Both UVA and UVB arrive at the Earth surface and may cause skin cancer and cataract in the case of large exposure [2]. Therefore, counterintuitively, UVC is thought to be safer for people, because proteins in the outer layer of dead skin cells absorb it before reaching the DNA in the living cells. However, UVC can irritate skin and eyes, and that is why the use of the light is usually restricted to be above people's heads, or in unoccupied rooms. The irritation usually clears up within a couple of days [1]. UVC lamps are installed within ventilation air ducts, out of sight and completely shielded from people.

UV radiation is considered as a major cause for skin tumors, particularly the malignant melanoma. Brenner and Hearing [3] had clearly highlighted the major acute and chronic effects of UV radiation on human skin, the properties of melanin, the regulation of pigmentation and its effect on skin cancer prevention.

The total solar radiation consists of $\sim 50 \%$ visible light, $\sim 40 \%$ infrared light

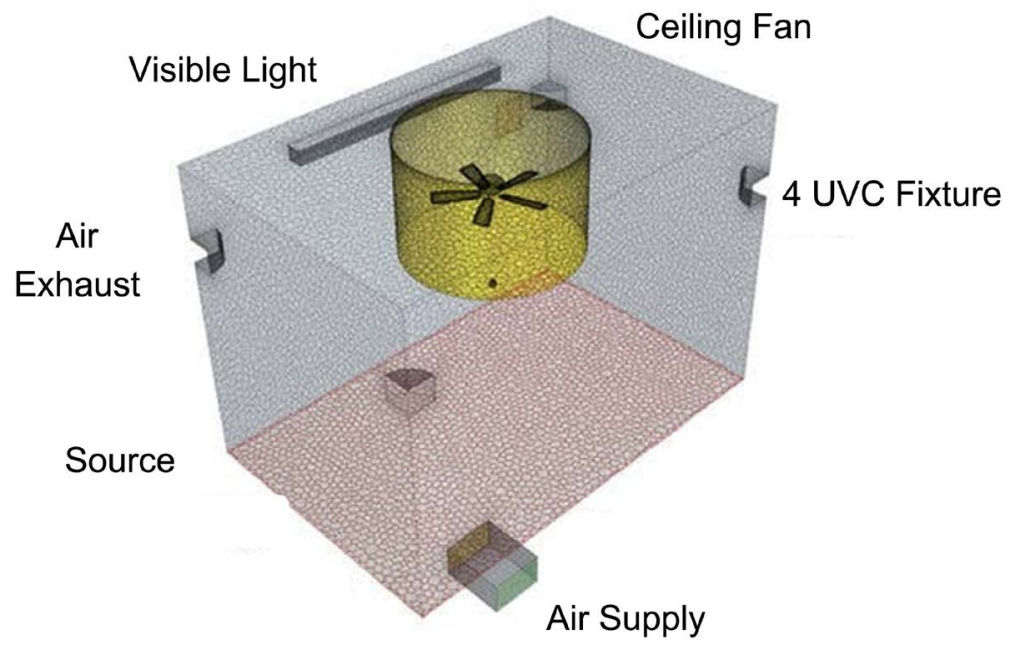

Figure 1. Four UVC lights fitted in the corners of a room. The ceiling fan is to draw air upward and effectively remove pathogens [1]. 
and $\sim 9 \%$ UV light. There are three types of UV radiation and are classified according to their energy, $E$ (and hence their wavelength, $\lambda$ ); the more energy the shorter the wavelength (as $E=h c l \lambda$, where $h$ is Plank constant and $c$ is the speed of light). These three types of UV radiation are:

1) UVA ( $\lambda=320$ to $400 \mathrm{~nm}$ ), which is about $8 \%$ of the solar radiation reaching Earth).

2) UVB ( $\lambda=280$ to $320 \mathrm{~nm}$ ) which is about $1 \%$ of the solar radiation reaching Earth and leads to carcinogenesis if Ozone layer is depleted [4].

3) UVC ( $\lambda=200$ to $280 \mathrm{~nm})$ which is blocked by atmospheric oxygen and absorbed by the ozone layer [5].

The intensity of UVA and UVB varies according to season, time of the day and the latitude of the location; the closer to latitude 23.45 ( $\mathrm{N}$ or S) the more UV intensity is recorded [6] [7]. The UV radiation in Bahrain was studied as early as 1992 [8] [9]. The solar ultraviolet-B radiation measurements of wavelength interval 295 - $385 \mathrm{~nm}$ were introduced between 1985 and 1989 using an Eppley Ultraviolet Radiometer [8]. The Long-term changes in solar UV radiation of wavelengths $295 \mathrm{~nm}$ to $385 \mathrm{~nm}$ exhibits reduction in UV intensity during summer months in each year. The annual average ratio of UV intensity to the average global solar intensity was $3.87 \%$, with a lowest value of $3.3 \%$ and a highest value of $4.35 \%$. This means that the average daily UV in Bahrain is about 30 $\mathrm{W} / \mathrm{m}^{2}$ [8]. This result is in line with other reported measurement studies for Bahrain [9]. These studies reported that the monthly average UV radiation was (wavelength $295-385 \mathrm{~nm}$ ) of $260 \mathrm{Wh} / \mathrm{m}^{2}$ (daily average of $26.5 \mathrm{~W} / \mathrm{m}^{2}$ ) for the period from 1986 to 1989, while the annual solar radiation in Bahrain during the same period was $64,547 \mathrm{Wh} / \mathrm{m}^{2}$, i.e. daily average of $580 \mathrm{~W} / \mathrm{m}^{2}$. This means that UV radiation represents $4.6 \%$ of the total solar radiation.

Several artificial sources for producing UV radiation have been devised such as tanning booths, black lights, curing lamps, germicidal lamps, mercury vapor lamps, halogen lights, high-intensity discharge lamps, fluorescent and incandescent sources, and some types of lasers [10]. High-Pressure Mercury Lamps (HPML) produce UVC light artificially and they radiate bright blue-white UVC radiation. HPML are widely used in industrial water treatment due to their intense radiation. Excimer Lamps emit narrow-band UVC and vacuum-ultraviolet radiation at a variety of wavelengths depending on the medium. They are mercury-free and reach full output quicker than a mercury lamp and generate less heat. Excimer emission at $207 \mathrm{~nm}$ and $222 \mathrm{~nm}$ appears to be safer than traditional $254 \mathrm{~nm}$ germicidal radiation, due to greatly reduced penetration of these wavelengths in human skin [10].

Light Emitting Diodes (LEDs) use semiconductor materials to produce light using solid-state materials. The wavelength of emission from this device is selected by adjusting the chemistry of the semiconductor material used, offering an option for selectivity emission profile of the LED across, and beyond, the germicidal wavelength band [10].

The effect of UVC on Bacteria and Viruses was reported as early as 1977 [11]. 
The effects of temperature and of ultraviolet radiation on the multiplication of bacteriophage $\varphi 29$ (a small virulent virus of Bacillus subtilis0n, were studied. Samples were exposed to larger UVC dose developed with less burst size, at certain temperature $\left(37^{\circ} \mathrm{C}, 42^{\circ} \mathrm{C}\right.$ and $\left.43.5^{\circ} \mathrm{C}\right)$. Unexposed viruses to UVC did not exhibit any change in burst size at $42^{\circ} \mathrm{C}$ and $37^{\circ} \mathrm{C}$ but at $43.5^{\circ} \mathrm{C}$ the burst size decreased substantially. When exposing a virus to a certain dose, the burst size decreased only if temperature was raised.

Jacquet and Bratbak [12] studied the effect of UVB intensity of $0.22 \mathrm{~W} / \mathrm{m}^{2}$ and the UVA/UVB ratio of 30) on five different cultured marine phytoplankton host virus systems. They concluded that viruses appear to be susceptible to UV but may provide some protection to their hosts. They also reported the following:

1) Some Microalgae are less sensitive to UVB influence compared to susceptible microalgae (i.e. virus-free cultures).

2) Not all viruses' responses are identical to UVB exposure; abundance patterns and infectivity.

3) UVA exposure has no effect on host virus interactions.

4) UVB exposure is an important factor in the regulation of virus host interactions in water surfaces.

Yin et al. [13] attributed the difference in the efficiency of UVC light on certain types of pathogens to the diverse structural features of the cell walls of bacteria and fungi. They concluded that these are the main reasons for the different killing rates. Further, they found that the different devices that deliver UVC with different power densities also induced different outcomes. More details about UVC germicidal efficacies are presented in Table 1.

Table 1. UVC germicidal efficacies [13].

\begin{tabular}{|c|c|c|c|}
\hline Light Source & Radiant Exposure & Bacterial/Fungi species/strains & Inactivation efficacy \\
\hline $254 \mathrm{~nm}$ UVC & $15.54 \mathrm{~mW} / \mathrm{cm}^{2}$ & $\begin{array}{l}\text { MRSA, VRE antibiotic susceptible strains of } S . \\
\text { aureus and } E \text {. faecalis }\end{array}$ & $\begin{array}{l}\text { Illuminated } 5 \text { seconds, } 99.9 \% \text { MRSA and VRE } \\
\text { inactivation; illuminated } 9 \text { seconds, } 100 \% \text { MRSA } \\
\text { inactivation; illuminated } 45 \text { seconds, } 100 \% \text { VRE } \\
\text { inactivation }\end{array}$ \\
\hline $254 \mathrm{~nm}$ UVC & $5 \mathrm{~mW} / \mathrm{cm}^{2}$ & MRSA, Streptococcus pyogenes & $\begin{array}{l}\text { Illuminated } 5 \text { seconds, methicillin-resistant, } \\
\text { coagulase-negative Staphylococcus and Streptococcus } \\
\text { pyogenes inactivation; Illuminated } 15 \text { seconds, } \\
\text { methicillin-susceptible } S \text {. aureus and Enterococci } \\
\text { species inactivation }\end{array}$ \\
\hline $265 \mathrm{~nm}$ UVC & $1.93 \mathrm{~mJ} / \mathrm{cm}^{2}$ & $\begin{array}{l}\text { S. aureus, E. coli, Pseudomonas aeruginosa, } S \text {. } \\
\text { pyogenes }\end{array}$ & Illuminated 1 seconds, $100 \%$ inhibition for all strains \\
\hline $254 \mathrm{~nm}$ UVC & $120 \mathrm{~mJ} / \mathrm{cm}^{2}$ & $\begin{array}{l}\text { Trichophyton rubrum, T. mentagrophytes, Epi- } \\
\text { dermophyton floccosum, Microsporum canis. }\end{array}$ & $3-5 \log 10$ of fungal inactivation \\
\hline UVC & $15.54 \mathrm{~mW} / \mathrm{cm}^{2}$ & $\begin{array}{l}\text { bacteria (P.aeruginosa and Mycobacterium ab- } \\
\text { scessus) and fungi (Candida albicans, } \\
\text { Aspergillus fumigatus) }\end{array}$ & $\begin{array}{l}\text { Illuminated } 3 \text { - } 5 \text { seconds, } 99 \% \text { bacteria inactivation; Illu- } \\
\text { minated } 15 \text { - } 30 \text { seconds, } 99 \% \text { fungi inactivation }\end{array}$ \\
\hline
\end{tabular}


Alcantara-Diaz et al. [14] studied the divergent adaptation of $E$. coli to cyclic high UVC dose at wavelength $254 \mathrm{~nm}$. In their study, five cultures E. coli PQ30 were exposed to 80 consecutive bacterial inactivation using UVC regrowth. The initial does of UVC was $1 \mathrm{~mJ} / \mathrm{cm}^{2}$ for each cycle and was increased 2 -fold every 10 inactivation-regrowth cycles. The researchers found that all cultures develop different level of resistance to UVC dose after 80 consecutive cycles of sub-lethal bacterial inactivation and regrowth. The adaptation of bacteria to cyclic UVC inactivation was attributed to be a consequence of selecting mutations in those genes due to DNA repair and replication.

In their latest review [15], UVC radiation was found to be an effective measure for disinfecting surfaces contaminated by the SARS-CoV2 virus by inducing photo-dimers in the genomes of microorganisms. UVC radiation is thought to be capable of destroying viruses (but not SARS-CoV2), bacteria and fungi in hundreds of laboratory studies [16]. The susceptibility of SARS-CoV2 toward UVC radiation was not thoroughly tested and reported; however, Sars coronavirus and other related coronaviruses are believed to be highly susceptible to UVC inactivation [13]. Among, the controversial debate is that SARS-CoV-2 virus is estimated to survive for 9 days on surfaces based on its similarity to SARS and MERS [15].

Up to date, there is uncertainty on the effect of UVC on SARS-CoV2. This lead ASHRAE [17] recommends that UVC is a strategy to impedes and fight SARS-CoV2 disease. However, it was advised that it is only after the completion of the manual chemical distinction UVC radiation can be used to disinfect equipment and surfaces from SARS-CoV2 [12]. Therefore, we took the initiative to study the effectiveness of using a commercial UVC light (Krypton Disinfection Lighting) on SARS-CoV2 and other Bacteria. This UVC is either fixed or portable. It has $15 \mathrm{~W}$ power (12 DCV) and can be operated $120 \mathrm{VAC}$ or $240 \mathrm{VAC}$ sources.

\section{Methodology}

Krypton Disinfection lighting CM15W12V Series was tested (Figure 2). FAR UV Technologies manufactured the light. The device is sold and marketed as a light disinfection (wavelength of $222 \mathrm{~nm}$ ).

According to the manufacturer, this UVC lamp is expected to be effective in warping infectious disease and pathogens in occupied spaces. It should continuously disinfect any known virus, bacteria or fungi; a process that is essential for the prevention of viruses transfer (SARS-CoV2) between people in occupied locations [18].

\section{Methods of Testing the UVC against Bacteria and Fungus:}

1) Certain types of microbes; Staph. aureus, E. coli, and Moulds (Aspergillus flavus) have been inoculated in Buffer Peptone Water BPW and kept @ $37^{\circ} \mathrm{C}$ for 18 - $24 \mathrm{hr}$ (overnight).

2) Serial dilutions of the cultured microbes from step 1 have been made; $10^{-1}$, $10^{-2}, 1 / 10^{-3}, 1 / 10^{-4}$ and $1 / 10^{-5}$ were used for the experiment. 

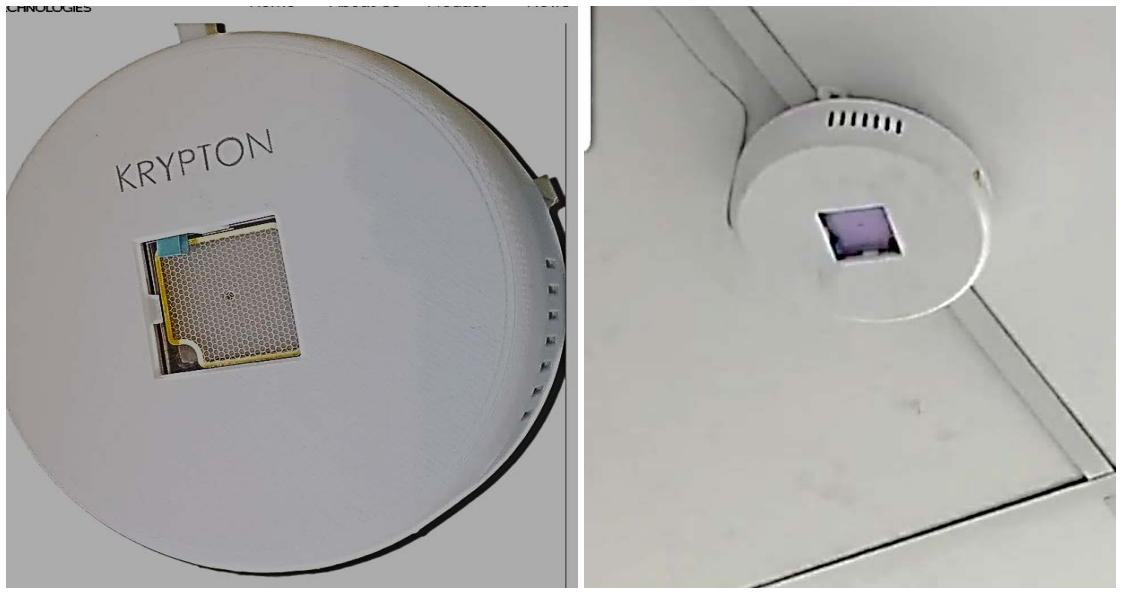

Figure 2. Krypton disinfection lighting CM15W12V Series. The lamp was fixed in the ceiling of the test room at ministry of health, kingdom of Bahrain.

3) Swabs from both concentrated (undiluted) and diluted bacterial and fungal cultures were used to inoculate Nutrient agar and Oxytetracycline-Glucose-Yeast Extract Agar (OGYE Agar), respectively, (Figure 3).

4) One set of the inoculated culture media was a control sample without exposure to UVC light and the other used as a test sample with exposure to UVC light, Figure 4.

5) Each of the diluted cultures of the test sample was exposed to UV light from the instrument on timely intervals of $10 \mathrm{sec}, 20 \mathrm{sec}, 30 \mathrm{sec}, 60 \mathrm{sec}$ and 40 minutes with a distance of 4 to $5 \mathrm{~cm}$ above the plate (Table 2 and Table 3 ).

\section{Methods of Testing the UVC against SARS-CoV2:}

1) Two rooms in this trial were used. In the first room the Krypton UVC device was fixed on the specified roof site in center of the area at a height of $2.9 \mathrm{~m}$ from the ground level and $2 \mathrm{~m}$ height from the bench. The other room was used for the control sample away from UV light device effect.

2) In the first room, UVC light was fixed in three positions in $10 \mathrm{~m}^{2}$ to cover the area as illustrated in the manual of the instrument; $(2 \mathrm{~m})$ on the table, $(2.9$ $\mathrm{m})$ in the center directly under the UV light device, and $(2.9 \mathrm{~m})$ on the edge of $10 \mathrm{~m}^{2}$ of the area specified.

3) In the second room, there was no exposure to the UV light, one position (2 $\mathrm{m}$ ), distance below the roof on the table marked and used as a control for the trail.

4) The trial was run using distance and time intervals from UV device; $2 \mathrm{~m}$ and $2.9 \mathrm{~m}$ for exposure duration of 15, 30, 60, 90 minutes and a day (Overnight).

5) A mixture of two known positive SARS-CoV2 samples with CT value 19 \& 15 were used to spike two sets of sterile Petri dishes.

6) The first set of sterile Petri dishes spiked by distributing of several drops of $5 \mu \mathrm{L}$ of SARS-CoV2 positive samples, and the other spiked by spreading the samples on sterile Petri dishes using swab dipped in positive SARS-CoV2 samples. This makes a total of 40 samples in this trial plus 2 positive known SARS-CoV2 samples. 

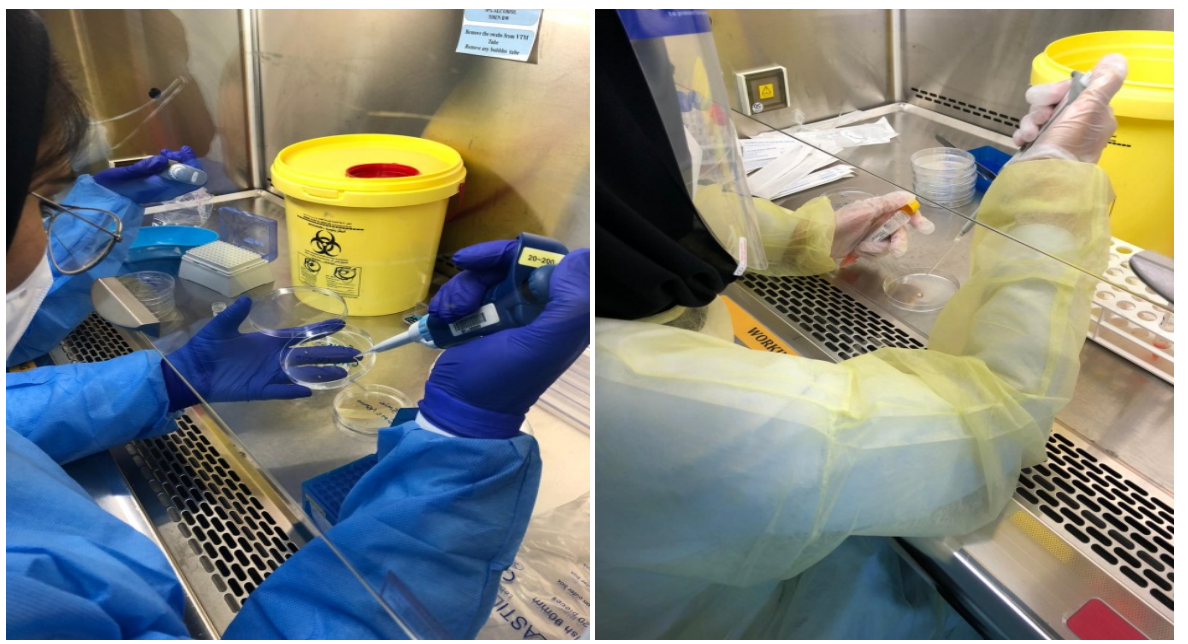

Figure 3. Environment at public health laboratory in preparing samples of bacteria and fungus to study their response after exposure to UVC radiation.
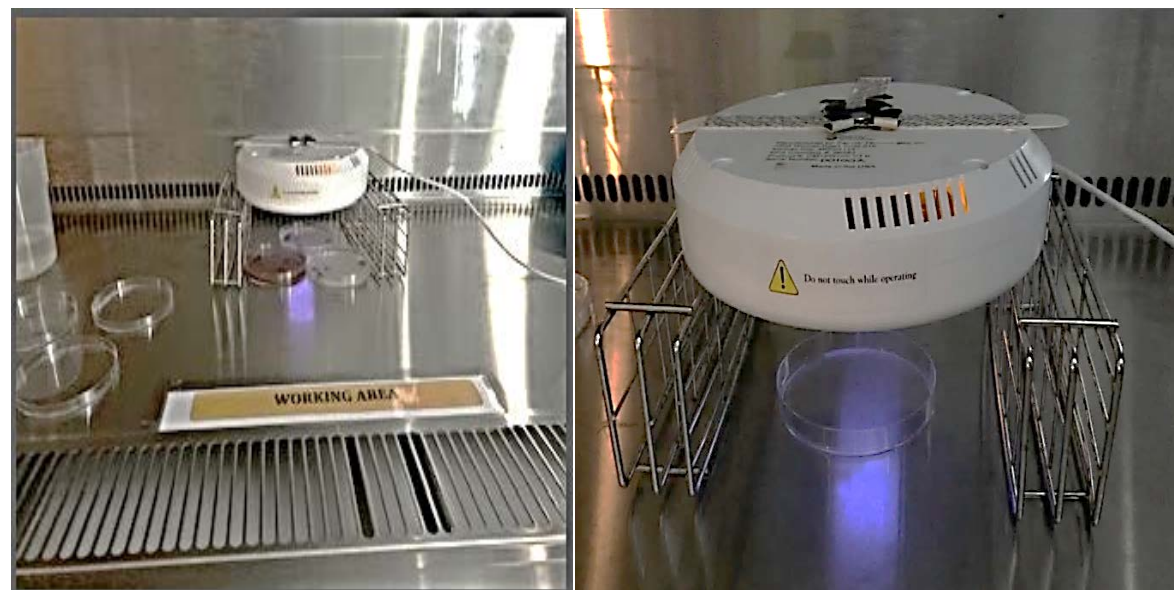

Figure 4. UVC radiation, using krypton disinfection lighting CM15W12V series, to different microbial cultures (Bacteria, Fungi and SARS-CoV2) at a height of $4-5 \mathrm{~cm}$ for different time 10, 20, 30, 60 seconds, 40 minutes and a day (Overnight).

Table 2. Result of microbial culture (Staph aureus \& E. coli) with and without exposure to UVC Krypton Disinfection lighting CM15W12V series. The UVC was $4-5 \mathrm{~cm}$ above the culture plates.

\begin{tabular}{|c|c|c|c|c|c|c|c|c|c|c|c|}
\hline \multirow[b]{2}{*}{ Condition } & \multirow{2}{*}{$\begin{array}{c}\text { Time } \\
\text { Intervals }\end{array}$} & \multicolumn{2}{|c|}{ Dilution $10^{-1}$} & \multicolumn{2}{|c|}{ Dilution $10^{-2}$} & \multicolumn{2}{|c|}{ Dilution $10^{-3}$} & \multicolumn{2}{|c|}{ Dilution $10^{-4}$} & \multicolumn{2}{|c|}{ Dilution $10^{-5}$} \\
\hline & & $\begin{array}{l}\text { E. coli } \\
\text { CFU }\end{array}$ & $\begin{array}{c}\text { Staph aureus } \\
\text { CFU }\end{array}$ & $\begin{array}{l}\text { E. coli } \\
\text { CFU }\end{array}$ & $\begin{array}{c}\text { Staph aureus } \\
\text { CFU }\end{array}$ & $\begin{array}{l}\text { E. coli } \\
\text { CFU }\end{array}$ & $\begin{array}{c}\text { Staph aureu. } \\
\text { CFU }\end{array}$ & $\begin{array}{c}\text { sE. coli } \\
\text { CFU }\end{array}$ & $\begin{array}{c}\text { Staph aureus } \\
\text { CFU }\end{array}$ & $\begin{array}{l}\text { E. coli } \\
\text { CFU }\end{array}$ & $\begin{array}{l}\text { Staph aureus } \\
\text { CFU }\end{array}$ \\
\hline \multirow[t]{3}{*}{$\begin{array}{l}\text { Without UV } \\
\text { (Control) }\end{array}$} & Overnight & TNTC & TNTC & TNTC & TNTC & TNTC & TNTC & 350 & 180 & 70 & 17 \\
\hline & $10 \mathrm{sec}$ & TNTC & TNTC & TNTC & TNTC & TNTC & TNTC & 295 & 165 & 18 & 15 \\
\hline & $20 \mathrm{sec}$ & TNTC & TNTC & TNTC & TNTC & TNTC & TNTC & 281 & 142 & 8 & 12 \\
\hline \multirow[t]{3}{*}{ Exposure to UV } & $30 \mathrm{sec}$ & TNTC & TNTC & TNTC & TNTC & TNTC & TNTC & 277 & 138 & 8 & 11 \\
\hline & $60 \mathrm{sec}$ & TNTC & TNTC & TNTC & TNTC & TNTC & TNTC & 196 & 100 & 3 & 4 \\
\hline & 40 minutes & TNTC & TNTC & TNTC & TNTC & NIL & NIL & 107 & 83 & $<1$ & $<1$ \\
\hline
\end{tabular}

CFU: Colony Forming Unit; TNTC: Too Numerous To Count. 
Table 3. Result of microbial culture (Aspergillus flavus) with and without exposure to UVC krypton disinfection lighting CM15W12V series. The UVC was $4-5 \mathrm{~cm}$ above the culture plates.

\begin{tabular}{ccccccc}
\hline \multirow{2}{*}{ Condition } & Time Intervals & $\begin{array}{c}\text { Dilution } \\
10^{-1}\end{array}$ & $\begin{array}{c}\text { Dilution } \\
10^{-2}\end{array}$ & $\begin{array}{c}\text { Dilution } \\
10^{-3}\end{array}$ & $\begin{array}{c}\text { Dilution } \\
10^{-4}\end{array}$ & $\begin{array}{c}\text { Dilution } \\
10^{-5}\end{array}$ \\
\hline Without UV (Control) & Overnight & $670 \mathrm{CFU}$ & $40 \mathrm{CFU}$ & $20 \mathrm{CFU}$ & $8 \mathrm{CFU}$ & $4 \mathrm{CFU}$ \\
& $10 \mathrm{sec}$ & $211 \mathrm{CFU}$ & $20 \mathrm{CFU}$ & $12 \mathrm{CFU}$ & $6 \mathrm{CFU}$ & $<1 \mathrm{CFU}$ \\
& $20 \mathrm{sec}$ & $193 \mathrm{CFU}$ & $14 \mathrm{CFU}$ & $4 \mathrm{CFU}$ & $2 \mathrm{CFU}$ & $<1 \mathrm{CFU}$ \\
Exposure to UV & $30 \mathrm{sec}$ & $100 \mathrm{CFU}$ & $1 \mathrm{CFU}$ & $2 \mathrm{CFU}$ & $1 \mathrm{CFU}$ & $<1 \mathrm{CFU}$ \\
& $60 \mathrm{sec}$ & $18 \mathrm{CFU}$ & $<1 \mathrm{CFU}$ & $<1 \mathrm{CFU}$ & $<1 \mathrm{CFU}$ & $<1 \mathrm{CFU}$ \\
& 40 minutes & $<1 \mathrm{CFU}$ & $<1 \mathrm{CFU}$ & $<1 \mathrm{CFU}$ & $<1 \mathrm{CFU}$ & $<1$ \\
\hline
\end{tabular}

CFU: Colony Forming; <1: No Growth.

7) All the spiked plates positioned in the area with the lid of plate open as shown in Figure 5.

8) Samples were taken by swabs from each of the spiked petri dishes in the specified time intervals.

9) RT-PCR test for SARS-CoV2 was performed directly after the collection of samples (Using WHO testing protocol); Figure 6.

\section{Results and Discussion}

Our results revealed that when exposing UVC to bacteria and Fungus, there was a substantial effect of UVC. The effect of UVC was found very systematic; the more UVC radiation time (exposure) to the pathogens the smaller number of microbial growth (E. coli, Staph. aureus and Aspergillus flavus (CFU/Swab).

For E. coli, at dilution $10^{-5}$, the CFU was 70 when it was kept overnight with no exposure to UVC. After 10 seconds the count decreased to 18; at 20 seconds exposure it was 8; at 30 seconds exposure it was also 8 but at 60 seconds exposure, it was 3 and at 40 minutes exposure there were no pathogens (Table $2 \&$ Table 3). It is worthy to note that the UVC intensity was about $30 \mathrm{~W} / \mathrm{m}^{2}(3$ $\mathrm{mW} / \mathrm{cm}^{2}$ ).

When exposing UVC to samples of positive RT-PCR (SARS-CoV2) test, with and without exposure to UVC Krypton Disinfection lighting CM15W12V Series, close to UVC light ( $4-5 \mathrm{~cm}$ above the culture plates), no affect was noticed. The exposure intensity was approximately $\left(3 \mathrm{~mW} / \mathrm{cm}^{2}\right.$ or $\left.30 \mathrm{~W} / \mathrm{m}^{2}\right)$ which is less than the UVC power density used for Virus MRSA and VRA (First row in Table 1) by 3 times. Table 4 displays the results of the test.

Testing the efficiency of UVC radiation, using Krypton Disinfection lighting, after been fixed in the ceiling of the laboratory room at $2 \mathrm{~m}$ above the culture (on the bench) and above $2.9 \mathrm{~m}$ (on the ground), it was noticed that UVC had no effects in this case either (Table 5).

The results show that Bacteria and Fungus were noted after different UVC exposure (10, 30, 60, 90 min and next day) in both Droplets of $5 \mu \mathrm{L}$ and Swabs. 


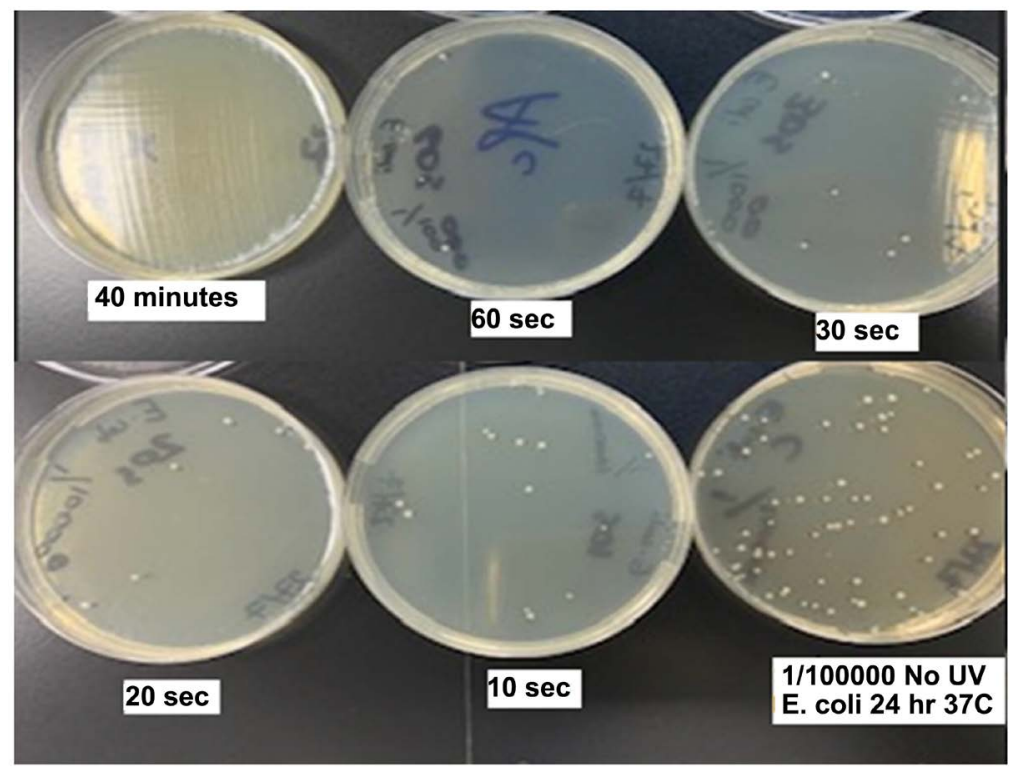

Figure 5. E. coli plates with dilution of $1 / 100,000$ with no exposure to UVC (as control) and then with exposure to UVC (using Krypton Disinfection lighting CM15W12V Series) at time intervals $10 \mathrm{~s}, 20 \mathrm{~s}, 30 \mathrm{~s}, 60 \mathrm{~s}$ and $40 \mathrm{~min}$. The UVC was $4-5 \mathrm{~cm}$ above the culture plates.
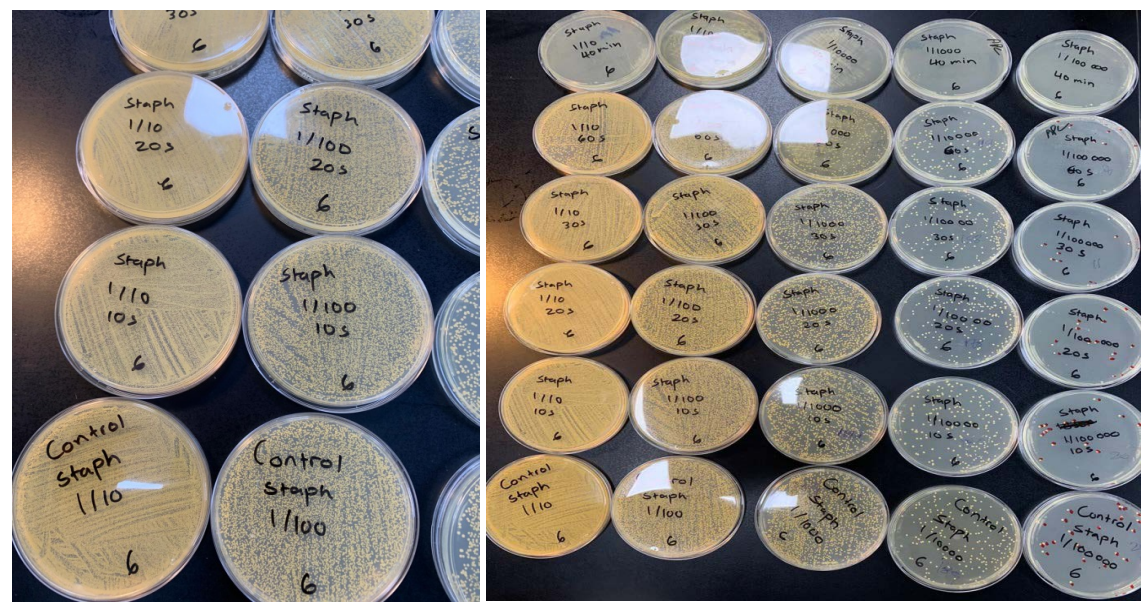

Figure 6. Staph. aureus plates with serial dilutions from $10^{-1}-10^{-5}$ after exposure to UVC at time intervals $10 \mathrm{~s}, 20 \mathrm{~s}, 30 \mathrm{~s}, 60 \mathrm{~s}$ and $40 \mathrm{~min}$.

Table 4. Result of RT-PCR (SARS-CoV2) with and without exposure to UVC krypton disinfection lighting CM15W12V series. The UVC was $4-5 \mathrm{~cm}$ above the culture plates.

\begin{tabular}{ccc}
\hline Condition & Time Intervals & COVID 19 positive samples \\
\hline Without UV (Control) & Overnight & Target Detected (Positive) \\
$10 \mathrm{sec}$ & Target Detected (Positive) \\
$20 \mathrm{sec}$ & Target Detected \\
Exposure to UV & $30 \mathrm{sec}$ & Target Detected \\
& $60 \mathrm{sec}$ & Target Detected \\
& 40 minutes & Target Detected
\end{tabular}


Table 5. Result of spiked sterile Petri dishes with and without exposure to UV light.

\begin{tabular}{|c|c|c|c|c|c|c|c|c|c|c|c|}
\hline & \multirow{2}{*}{$\begin{array}{l}\text { Distance from } \\
\text { Source }\end{array}$} & \multicolumn{5}{|c|}{ Droplet of $5 \mu \mathrm{L}$} & \multicolumn{5}{|c|}{ Swab } \\
\hline & & $15 \mathrm{~min}$ & $30 \mathrm{~min}$ & $60 \mathrm{~min}$ & $90 \mathrm{~min}$ & Next day & $15 \mathrm{~min}$ & $30 \mathrm{~min}$ & $60 \mathrm{~min}$ & $90 \mathrm{~min}$ & Next day \\
\hline \multirow{6}{*}{$\begin{array}{c}\text { Exposure to UV } \\
\text { light }\end{array}$} & \multirow{2}{*}{$\begin{array}{c}2 \mathrm{~m} \\
\text { on Bench }\end{array}$} & $\mathrm{TD}$ & TD & TD & TD & TND & $\mathrm{TD}$ & TD & TD & $\mathrm{TD}$ & TD \\
\hline & & CT: 21 & CT: 21 & CT: 23 & CT: 22 & CT: 0 & CT: 24 & CT: 23 & CT: 25 & CT: 25 & CT: 24 \\
\hline & $2.9 \mathrm{~m}$ & TD & TD & $\mathrm{TD}$ & TD & TD & TD & $\mathrm{TD}$ & $\mathrm{TD}$ & TD & TD \\
\hline & Center & CT: 22 & CT: 22 & CT: 23 & CT: 22 & CT: 22 & CT: 23 & CT: 23 & CT: 25 & CT: 24 & CT: 26 \\
\hline & \multirow{2}{*}{$\begin{array}{l}2.9 \mathrm{~m} \\
\text { Side }\end{array}$} & $\mathrm{TD}$ & TD & $\mathrm{TD}$ & TD & $\mathrm{TD}$ & TD & $\mathrm{TD}$ & TD & TD & $\mathrm{TD}$ \\
\hline & & CT: 22 & CT: 24 & $\mathrm{CT}: 25$ & CT: 22 & CT: 22 & CT: 26 & CT: 25 & CT: 25 & CT: 20 & CT: 28 \\
\hline \multirow{2}{*}{ No UV } & \multirow{2}{*}{ On Bench } & $\mathrm{TD}$ & $\mathrm{TD}$ & $\mathrm{TD}$ & $\mathrm{TD}$ & TND & $\mathrm{TD}$ & $\mathrm{TD}$ & TD & $\mathrm{TD}$ & TD \\
\hline & & CT: 24 & CT: 23 & CT: 23 & CT: 34 & CT: 0 & CT: 24 & CT: 22 & CT: 22 & CT: 34 & CT: 24 \\
\hline
\end{tabular}

TD: Target Detected; TND: Target Not Detected; Original Positive samples CT was 19 \& 1 .

This is different from the previous test where the UVC source was put at a distance $4-5 \mathrm{~cm}$ from the culture. Herein, the UVC exposure intensity delivered to the pathogens, when are $2 \mathrm{~m}$ below UVC light, is about $2 \mu \mathrm{W} / \mathrm{m}^{2}$ while it may have an exposure intensity about $1.0 \mu \mathrm{W} / \mathrm{cm}^{2}$, when are $2.9 \mathrm{~m}$ below UVC light, as intensity dropped by power 4 if distance is doubled; Equation (1):

$$
I_{d}=I_{c}\left(D_{c} / D_{d}\right)^{2}
$$

$I_{d}$ is UVC intensity at large distance, $D_{d}(2.0 \mathrm{~m}$ or $2.9 \mathrm{~m}), I_{c}$ is UVC intensity at close distance, $D_{c}(4-5 \mathrm{~cm})$.

The results seem contradictory especially that UVC has an effect on Bacteria and Fungus at short distance (intensity $3 \mathrm{~mW} / \mathrm{cm}^{2}$ ) but not on virus SARS-CoV2 exposed to similar exposure intensity. One possible explanation is that the RNA is more UV resistant than the DNA [19]. Moreover, the Ultraviolet light kills cells by damaging their DNA. The light initiates a reaction between two molecules of thymine; a core constituent that makes up the DNA. The longer the exposure to UV light, the more thymine dimers are formed in the DNA and the greater the risk of an incorrect repair or a "missed" dimer [20].

It is also worth mentioning that UVC light is better fixed at the corners, close to the ground, instead of fixing them up. This will allow UVC to kill pathogens which are usually deposited on ground (sneezing, coughing, sticked to shoes, etc) due to gravity.

Our research disagrees with other studies on the effect of UVC on pathogenic viruses and a virulent [21]. Our working wavelength is $222 \mathrm{~nm}$, which is known as the most active antimicrobial UV wavelengths (range of 185 to $280 \mathrm{~nm}$ ) that are highly absorbed by nucleic acids. Although UVB (280 to $320 \mathrm{~nm}$ ), known as environmentally effective virucidal radiation, and UVA (320 to $400 \mathrm{~nm}$ ), abundant in GCCC sunlight, has a much lower effect on viruses and other microbial agents, observations and reported SARS-CoV2 cases do not support this conclusion. 
Exposing UVB radiation consciously to Newcastle Disease Virus (NDV) and pathogenic influenza (HPAJ) will result in their infectivity declination with time. For NDV, it takes $1 \mathrm{~h} 9 \mathrm{~min}$, for $\mathrm{H}_{7} \mathrm{~N}_{1} \mathrm{HPAI}$ virus, it takes $2 \mathrm{~h} 38 \mathrm{~min}$, and for $\mathrm{H}_{5} \mathrm{~N}_{1}$ HPAJ virus, it takes $2 \mathrm{~h} 47 \mathrm{~min}$ [21]. These observations do not seem to agree with ours in this study though we were focusing on SARS-CoV2.

UV radiation affect human being, in particular UVA (315 - $400 \mathrm{~nm})$ and UVB $(280-315 \mathrm{~nm})$, and the risk related to their exposure depends on human activities and behavior; its increases as the outdoor activities increases. It was thought that SARS-CoV2 will be less active as its exposed to such radiation, but actual data shows that this is not fully true. The infection rate in hot and arid countries like Bahrain, Saudi Arabia, United Arab Emirates, Kuwait and Iraq is high. Researches thought that countries with high Ultraviolet Index (UVI) may register less rate of positively infected people. UVI covers radiation from $280 \mathrm{~nm}$ to $400 \mathrm{~nm}$ and it ranges from 0 to 16 . UVI can be calculated using the minimal erythemal dose (defined as the threshold dose that may produce sunburn) and is high in summer and low in winter [22] [23]. Therefore, it was advisable to install UV meters in secondary schools as a sun protection intervention mechanism for adolescents specially in countries of high UVI which will have two folds, i.e. protection from UV and indicating germs and virus inactivation due to exposure to UV. According to UV meter suggested by Cancer Council, UVI from 1 - 2 no protection needed, from 3 to 7 protection required and from 8 to $11^{+}$people must seek shade, i.e. viruses may inactivated or partially immolated [24].

Architects adopted UV light fixture for disinfection in their new design for senior housing for safe interaction as part of the role of architecture in fighting SARS-CoV2. They similarly think that UV disinfection lights, beside other practice like air filters and fans create negative air pressure environments [25]. However, there remains the question whether they are aware that UVC light does not seem to be effective on SARS-CoV2 as is the case with Bacteria and Fungus, even if the UVC light is put so close to the viruses.

In addition, quarantine has led architects to think how to avoid the lack of daylight in a room (isolation room), the dirty floor, the need for an extra bathroom, space of the living room and the use of UVC lights [26].

Some architects have strong beliefs that buildings can be free from SARS-CoV2, especially now that students and employees are preparing to return to schools, universities and offices, if UVC light is fixed in the study or workspaces in order to reduce harmful pathogens. Further, other practices are suggested to be taken into consideration in all commercial properties such as 1) in-duct HVAC systems; 2) cooling coil units; 3) air movers; 4) upper room air purifiers [27].

This paper may lead architects to rethink and offer other alternatives in the design of buildings to combat and reduce pathogens attack.

\section{Conclusions}

The UVC emitted from a UVC LED ceiling light, called Krypton Disinfection lighting CM15W12V Series, has shown no effect on SARS-CoV2 to disintegrate 
its biological materials even when it is left for an overnight. Moreover, it has shown no apparent results when it is close to the Virus culture plate $(4-5 \mathrm{~cm})$ or at a distance ( 2.0 to $2.9 \mathrm{~m}$ ) when fixed in the ceiling of the test room. Only two samples in the next day of the trial showed no target detected (ve SARS-CoV2) and this might be due to dryness of the samples and not due to UV exposure.

This study addresses a very significant observation which may have some implications. It shows that commercially available UVC ceiling light has no effects on SARS-CoV2, although it is claimed to do so in some advertisements and catalogues. Authorities should carefully test these devices before launching them into the market. The public has the perception that commercial UVC ceiling light can kill SARS-CoV2 immediately while this is proven the opposite in this study.

It is also worthy to note that this study shows no effect of these UVC ceiling lights even when they are kept radiating SARS-CoV2 for overnight. This proves that the intensity of the UVC from these devices is relatively low.

However, this Krypton Disinfection lighting CM15W12V Series is effective in destroying Bacteria and Fungus, substantially, in $30 \mathrm{sec}$ and kills them completely in $60 \mathrm{~min}$. There is no significant change in the CT value for most of the samples tested compared to the original CT value in both the spiked Petri dishes (with droplets \& swabs). This observation indicates that UVC celling lights are effective in destroying Bacteria and Fungus (part of pathogens), i.e. they are bacteria disinfection devices. This novel conclusion should be highlighted as people may be attracted to purchase and install such UVC LED ceiling devices believing that it will disinfect their premises and houses from SARS-CoV2, especially with this second wave or resurgence in COVID-19 cases after successfully slowing outbreaks early in the year in Europe, India and Brazil, particularly where the lockdown is imposed again. This study shows clearly that this product (UVC LED ceiling devices) is completely not active nor fit for this purpose.

The solar radiation in Bahrain is so intense (annual daily average is 620 $\mathrm{W} / \mathrm{m}^{2}$ ) and the UV portion (UVA and B) represents about $4 \%\left(25 \mathrm{~W} / \mathrm{m}^{2}\right)$. Similar values are recorded in other Gulf Cooperation Council Countries (GCCC). For example, in Kuwait [28] the ratio of monthly daily ultraviolet to global solar radiation was found to range between $4.07 \%$ and $5.4 \%$, which is similar to the value in Bahrain (about 4.0\%). The highest and lowest intensity monthly-daily recorded values for global radiation in Kuwait were $9.29 \mathrm{Wh} / \mathrm{m}^{2}$ and 0.45 $\mathrm{kWh} / \mathrm{m}^{2}$ but for UV were $445 \mathrm{Wh} / \mathrm{m}^{2}$ and $31 \mathrm{Wh} / \mathrm{m}^{2}$, respectively.

UVA radiation is capable of penetrating deep into the skin and is thought to be responsible for up to $80 \%$ of skin ageing, from wrinkles to age spots [18]. Meanwhile, UVB radiation can damage the DNA in our skin, leading to sunburn and eventually skin cancer but our observation did not indicate that large UV intensity in a country had less SARS-CoV2 infection; GCCC had been hit badly by SARS-CoV2, counter to expectation. Nowadays, the society is keen to use UVC devices as some scientists claimed that they could harness UVC light to 
kill microorganisms, but our results show that UVC light cannot eliminate SARS-CoV2. It can do so, however, in the case of Bacteria and Fungus.

It has to be noted that genuine and well tested UVC devices, other than LED commercial ones, may disinfect or kill SARS-CoV2. Usually the UVC lights used in medicine are much more powerful than these commercial UVC LED lights. Unfortunately, to the best of our knowledge, no scientific work has been published to study the effect of UVC on SARS-CoV2 (COVID 19) to allow us to compare and reach a conclusion on why such UVC LED Ceiling types were not effective for SARS-CoV2 disinfection.

\section{Acknowledgements}

The authors thank the University of Bahrain (UoB) and the Ministry of Health, Kingdom of Bahrain, for their moral and logistic support to conduct this study. The authors are also grateful to Zahra J. AlAAli for her technical assistance. Thanks, are extended to Dr. Ghada Ahmed, director of English Language Centre at $\mathrm{UoB}$, for editing this paper.

\section{Conflicts of Interest}

The authors declare no conflicts of interest regarding the publication of this paper.

\section{References}

[1] Change, B.K. (2020) Scientists Consider Indoor Ultraviolet Light to Zap Coronavirus in the Air. New York Times, 7 May.

https://www.nytimes.com/2020/05/07/science/ultraviolet-light-coronavirus.html

[2] Lucas, J. (2017) Live Science, September 15. https://www.livescience.com/50326-what-is-ultraviolet-light.html\#: :text=One\%20 of $\% 20$ the $\% 20$ most $\% 20$ common,paints $\% 20$ and $\% 20$ dyes $\% 20$ to $\% 20$ glow

[3] Brenner, M. and Hearing, V.H. (2008) The Protective Role of Melanin Against UV Damage in Human Skin. Photochemistry and Photobiology, 84, 539-549. https://doi.org/10.1111/j.1751-1097.2007.00226.x

[4] De Fabo, E.C. (2005) Arctic Stratospheric Ozone Depletion and Increased UVB Radiation: Potential Impacts to Human Health. International Journal of Circumpolar Health, 64, 509-522. https://doi.org/10.3402/ijch.v64i5.18032

[5] Gilchrest, B.A., Eller, M.S., Geller, A.C. and Yaar, M. (1999) The Pathogenesis of Melanoma Induced by Ultraviolet Radiation. The New England Journal of Medicine, 340, 1341-1348. https://doi.org/10.1056/NEJM199904293401707

[6] Kripke, M.L. (1988) Impact of Ozone Depletion on Skin Cancers. The Journal of Dermatologic Surgery and Oncology, 14, 853-857. https://doi.org/10.1111/j.1524-4725.1988.tb03589.x

[7] Holzle, E. and Honigsmann, H. (2005) UV-Radiation-Sources, Wavelength and Environment. Journal Der Deutschen Dermatologischen Gesellschaft, 3, 3-10. https://doi.org/10.1111/j.1610-0387.2005.04392.x

[8] Som, A.K. (1992) Solar UV-B Radiation Measurement over Bahrain. Renewable Energy, 2, 93-98. https://doi.org/10.1016/0960-1481(92)90065-B 
[9] Alnaser, W.E. (1997) Solar Ultra-Violet Radiation Changes in Bahrain. Applied Energy, 57, 25-35. https://doi.org/10.1016/S0306-2619(96)00023-2

[10] Wikipedia, 2020. https://en.wikipedia.org/wiki/Germicidal lamp

[11] Larcom, L.L. and Thaker, N.H. (1977) The Effects of Temperature and Ultraviolet Irradiation on Multiplication of Bacteriophage Phi 29. Biophysics Journal, 19, 299-306. https://doi.org/10.1016/S0006-3495(77)85589-6

[12] Jacquet, S. and Bratbak, G. (2003) Effects of Ultraviolet Radiation on Marine Virus-Phytoplankton Interactions. FEMS Microbiology Ecology, 44, 279-289. https://doi.org/10.1016/S0168-6496(03)00075-8

[13] Yin, R., Dai, T., Avci, P., Jorge, E.A.S., de Melo, W., Vecchio, D., Huang, Y.Y., Gupta, A. and Hamblin, M.R. (2013) Light Based Anti-Infectives: Ultraviolet C Irradiation, Photodynamic Therapy, Blue Light, and Beyond. Current Opinion in Pharmacology, 13, 731-762. https://doi.org/10.1016/j.coph.2013.08.009

[14] Alcántara-Díaz, D., Breña-Valle, M. and Serment-Guerrero, J. (2004) Divergent Adaptation of Escherichia coli to Cyclic Ultraviolet Light Exposures. Mutagenesis, 19, 349-354. https://doi.org/10.1093/mutage/geh039

[15] Kowalski, W.J., Walsh, T.J. and Petraitis, V. (2020) COVID-19 Coronavirus Ultraviolet Susceptibility. PurpleSun, Inc., New York, 9.

https://www.researchgate.net/publication/339887436 2020 COVID-19 Coronaviru s Ultraviolet Susceptibility

[16] Kowalski, W.J. (2009) Ultraviolet Germicidal Irradiation Handbook: UVGI for Air and Surface Disinfection. Springer, New York.

https://doi.org/10.1007/978-3-642-01999-9

[17] ASHRAE (2020) ASHRAE Resources Available to Address COVID-19 Concerns. American Society of Heating, Refrigerating and Air-Conditioning Engineers, Atlanta, GA.

[18] Gorvett, Z. (2020) Can You Kill Coronavirus with UV Light? https://www.bbc.com/future/article/20200327-can-you-kill-coronavirus-with-uv-lig ht

[19] Kundu, L.M., Linne, Marahiel, U.M. and Carell, T. (2004) RNA Is More UV Resistant than DNA: The Formation of UV-Induced DNA. Chemistry, 10, 5697-5705. https://doi.org/10.1002/chem.200305731

[20] Rammelsberg, A. (1998) How Does Ultraviolet Light Kill Cells? The Sciences. https://www.scientificamerican.com/article/how-does-ultraviolet-ligh/

[21] Sutton, D., Aldous, E.W., Warren, C.J., Fuller, C.M., Alexander, D.J. and Brown, I.H. (2013) Inactivation of the Infectivity of Two Highly Pathogenic Avian Influenza Viruses and a Virulent Newcastle Disease Virus by Ultraviolet Radiation. Avian Pathology, 42, 566-568. https://doi.org/10.1080/03079457.2013.853867

[22] Pettigrew, S., Parnell, A., Strickland, M., Neale, R. and Lucas, R. (2020) The Potential of Ultraviolet Radiation Meters in Secondary Schools as a Sun Protection Intervention Mechanism for Adolescents. International Journal of Environmental Research and Public Health, 17, 1137-1147. https://doi.org/10.3390/ijerph17041137

[23] Ashidi, A.G, Ogunjo, S.T. and Toluwalope, M.A. (2019) Distribution Analysis and Autoregressive Modelling of Ultraviolet Radiation over Akure, Nigeria. International Journal of Environment and Health (IJENVH), 9, 289-305. https://doi.org/10.1504/IJENVH.2019.108659

[24] Cadet, J.-M., Portafaix, T., Bencherif, H., Lamy, K., Brogniez, C., Auriol, F., Metzger, J.-M., Boudreault, L.-E. and Wright, C.Y. (2020) Inter-Comparison Campaign 
of Solar UVR Instruments under Clear Sky Conditions at Reunion Island $\left(21^{\circ} \mathrm{S}, 55^{\circ} \mathrm{E}\right)$. International Journal of Environmental Research and Public Health, 17, 2867-2869. https://doi.org/10.3390/ijerph17082867

[25] MASS, Mass Design Group (2020) Designing Senior Housing for Safe Interaction: The Role of Architecture in Fighting COVID-19. 8 July.

https://massdesigngroup.org/sites/default/files/multiple-file/2020-07/Designing\%20 Senior\%20Housing\%20for\%20Safe\%20Interaction.pdf

[26] Chayka, K. (2020) How the Coronavirus Will Reshape Architecture. The New Yorker, 17 June.

https://www.newyorker.com/culture/dept-of-design/how-the-coronavirus-will-resh ape-architecture

[27] ProLampSales (2020) Posted by Nick on 10 April 2020.

https://www.prolampsales.com/blogs/specialty-architectural-lighting/uvc-disinfecti on-lighting-for-offices-and-commercial-buildings

[28] El-Nashar, N.F., Abdullah, A.H. and Al-Zenki, J.M. (2007) Solar Global and Ultraviolet Radiation Measurements over Kuwait. International Journal of Solar Energy, 21, 281-291. https://doi.org/10.1080/01425910108914376 